\title{
ÁSATÁSOK AZ ISTÁLLÓS-KŐI-BARLANGBAN ÉS AZ ÚJ KUTATÁSI EREDMÉNYEK
}

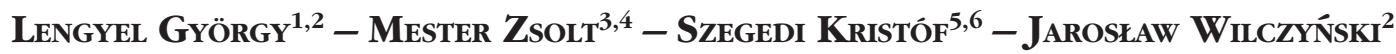
Magyar Régészet 10. évf. (2021), 4. szám, pp. 1-8. https://doi.org/10.36245/mr.2021.4.5

Az Istállós-köi-barlang a Szeleta mellett a legismertebb és a leglátogatottabb öskökori régészeti lelöhely Magyarországon (1. kép). Ez annak a ténynek köszönhetö, hogy a Szilvásváradhoz tartozó Szalajka-völgyben nyílik, amely a Bükk hegység legvonzóbb turisztikai célpontja. Bár szabadon látogatható, fokozott védelem alatt áll (SZÉKELY 2002). Ösrégészeti szempontból nemzetközileg is számon tartott lelöhely, mivel az Európába 40 ezer évvel ezelött érkezö anatómiailag modern ember (Homo sapiens) egyik legidösebb megtelepedése található itt. A lelöhely régészeti jelentösége megkivánja, hogy a legújabb kutatási módszerekkel újravizsgáljuk az emberi megtelepedéseket, ami lehetöséget ad számos aktuális kérdés tisztázására.

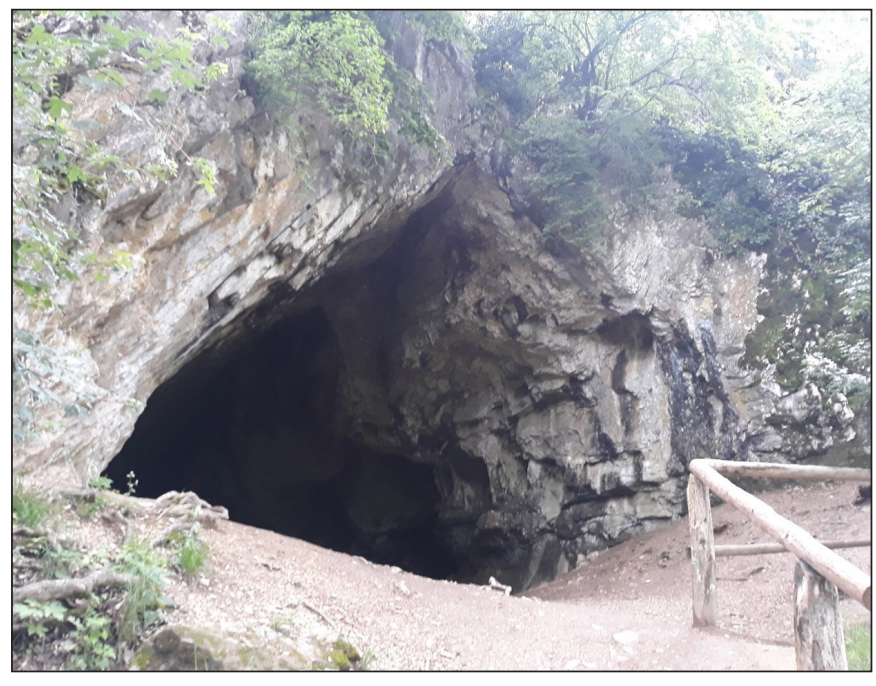

1. kép. Az Istállós-kői-barlang bejárata (2019. július)

Kulcsszavak: barlangi ásatás, őskőkor, Aurignacien kultúra, Bükk hegység

\section{A BARLANG KUTATÁSTÖRTÉNETE}

A barlang első ásatását 1911-ben - vagy 1912-ben, ami a szakirodalom alapján nem dönthető el egyértelműen - Hillebrand Jenő végezte próbafeltárás keretében (VÖRös 2003/2004). Hillebrand (1913) első meglátása alapján a barlang jégkori rétegei erősen bolygatottak voltak, amit az őskori cserepek sokasága jelzett. Felfigyelt arra is, hogy a rétegsorban, a sárga réteg alatt, $40-80 \mathrm{~cm}$-es mélységben jelentős tüzelésnyomok találhatók. Az egyik nagyméretü tüzhely feltárását 1913 és 1925 között több ásatáson át folytatta (HilleBrand 1914; 1917; 1919; KADIĆ 1927). 1917-ben a tüzhelynél három lapos kőből álló struktúrát figyelt meg, s leírása szerint a tüzhely kb. $40 \mathrm{~m}^{2}$ területen helyezkedett el (HiLleBrand 1919). A tüzhely sárga és vörösessárga agyagrétegek közé ékelődött, amelyek fölött a fekete humusz még a jelenkort, a meddő mészkőtörmelékes szürkés agyag viszont már a pleisztocént (dilúvium) képviselte.

1927-ben Saád Andor folytatta Hillebrand munkáját, aki a barlang hátsó részében jóval tagoltabb rétegsort írt le (SAÁD 1929):

- legfelül jelenkori humusz,

- szürke agyagos törmelék,

- $\quad$ sárga plasztikus agyag,

Miskolci Egyetem BTK Östörténeti és Régészeti Tanszék, 3515 Miskolc-Egyetemváros. E-mail: bolengyu@uni-miskolc.hu

2 Institute of Systematics and Evolution of Animals, Polish Academy of Sciences, 17 Sławkowska, Kraków, 31-016, Poland

3 Eötvös Loránd Tudományegyetem BTK Régészettudományi Intézet, 1088 Budapest, Múzeum krt. 4/B. E-mail: mester.zsolt@, btk.elte.hu

4 Histoire Naturelle de l'Homme Préhistorique (HNHP), Muséum national d'Histoire naturelle, CNRS, UPVD, 1 Rue René Panhard, 75013 Paris, Franciaország

5 Várkapitányság Integrált Területfejlesztési Központ Nonprofit Zrt., 1013 Budapest, Ybl Miklós tér 6.

6 Miskolci Egyetem, Mikoviny Sámuel Földtudományi Doktori Iskola, 3515 Miskolc-Egyetemváros 
- szürkéssárga törmelékes agyag,

- tüzhelyréteg,

- vörössárga agyag,

- tüzhelyréteg, és

- legalul sárga törmelékes agyag.

A tüzhelyekhez kapcsolódóan leleteket is talált. A felsőből egy „gravette penge” és az alsóból két csonteszköz került elö, amelyek közül az egyik a barlangnak az első hasított alapú hegye.

1929-ben Kadić Ottokár és 1938-ban Mottl Mária folytatta az ásatást a barlang több pontján, de leleteket nem említettek (KADIĆ \& MotTL 1944). A barlang hátsó szakaszában ők is megtalálták a Saád által leírt tűzhelyrétegeket. Költségszámításaik alapján a gyér leletanyag miatt a feltárások folytatását feleslegesnek ítélték.

Hillebrand $(1917 ; 1919)$ a tüzhelyben talált leleteket a nyugat-európai felső Aurignacien típusaihoz hasonlította, amelyet a hajógerinc alakú vakarók hiányával és a vésők hasonlóságával támasztott alá. Kadić és Mottl (1944) a leletek értékelésénél nagyfokú egyezést talált a szlovákiai Moravany leleteivel, így azokat a kései ,javaaurignaci” fázisra helyezték. Ez a kulturális beosztás a korabeli francia beosztáson alapult, amelynek a felső Aurignacien fázisa ma a Gravettien kultúrával azonos.

A második világháború előtti leletanyag tanulmányozása sok nehézségbe ütközik az ásatási dokumentációk hiánya miatt. Egyedül Kadić és Mottl (1944) publikált alap- és metszetrajzokat a barlangról, amelyekre alapozva készült Vértes László (1955) összesítő térképe (2. kép). Ezek alapján rekonstruálható az egykori ásatási területek elhelyezkedése (VöRös 2003/2004). Gyakorlatilag csak a Vértes László 1947 és 1951 között végzett feltárásaiból származó leleteket lehet jobban a rétegekhez kötni.

A barlang régészeti kronológiáját Vértes László kutatásai alapozták meg (VÉRTES 1955). Vértes (1957) elbeszéléséből tudjuk, hogy 1947-ben kifejezetten a Hillebrand által említett tüzhelyet akarta megtalálni. Az általa feltárt tüzhely kövekkel volt körbe rakva, amit annyira fontos leletnek tekintett, hogy a barlangból kiemelte és a Magyar Nemzeti Múzeumba szállította az akkor készülő régészeti kiállítás egyik attrakciójául (VÉRTES 1951). A tüzhely környékéröl föként Gravettien eszköztípusokat írt le, de a leletanyagot még mindig az idöközben új francia beosztás szerinti Aurignacien kultúra végére helyezte. Az 1948-as ásatás alkalmával a barlang első szakaszában a bejárattól kezdve egy 12 m hosszú árkot húzott befelé, amelyet fenekéig feltárt (VÉRTES 1951). 1950-1951-ben az árok két oldalán is fenékig kiásta a barlang első felének nagy részét. Így a $160 \mathrm{~m}^{2}$ felületen (VÉRTES 1955) 2,5 m-es átlagos rétegmélységgel számolva legalább $400 \mathrm{~m}^{3}$ üledéket távolított el a barlangból. Ennek a munkának köszönhető azonban az Aurignacien kultúra két fázisának, az Aurignacien I és II-nek a megtalálása, amelyeket a csontból/agancsból készített lándzsa-, dárda- és nyílhegyek típusai határoztak meg. Az alsó kultúrrétegben (Aurignacien I) a hasított alapú hegyek, míg a felette lévő kultúrrétegben (Aurignacien II) a Mladeč/Olschewien hegyek voltak gyakoriak. Vértes a kőeszközök között nem talált tipikus Aurignacien darabokat, és az elődei által használt kulturális beosztásból eredő Gravettien

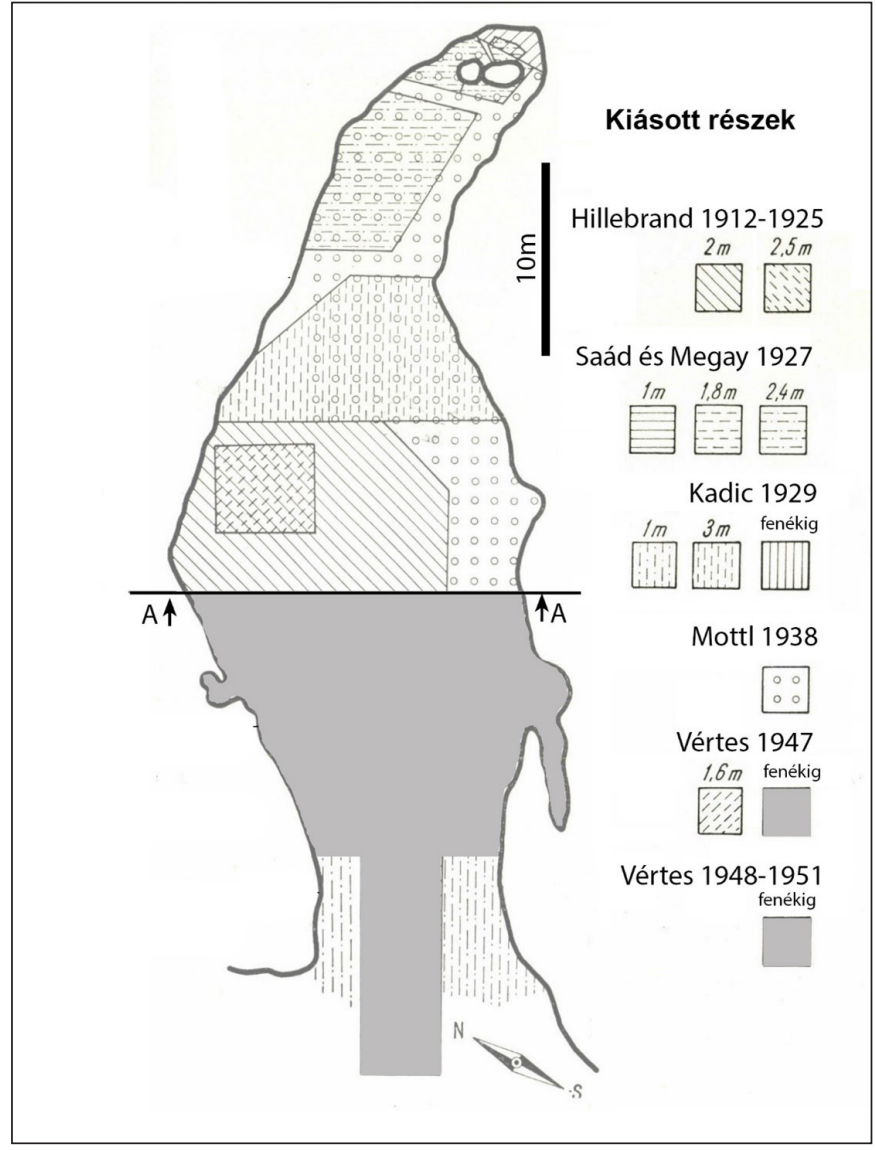

2. kép. Az Istállós-kői-barlang 2000 elött feltárt területei (VÉRTES 1955, Abb. 1) 
Lengyel György et al. • Ásatások az Istállós-köi-barlangban és az új kutatási eredmények

rokonságot is elvetette. Szerinte a második világháború elött feltárt leletek csak az Aurignacien II rétegének szintjéből származhatnak (VÉRTES 1955).

A barlangot kitöltő rétegsort Vértes (1955) a jelenkori járófelszín alatt öt pleisztocén rétegre tagolta, felülről lefelé az alábbi sorrendben (3. kép):

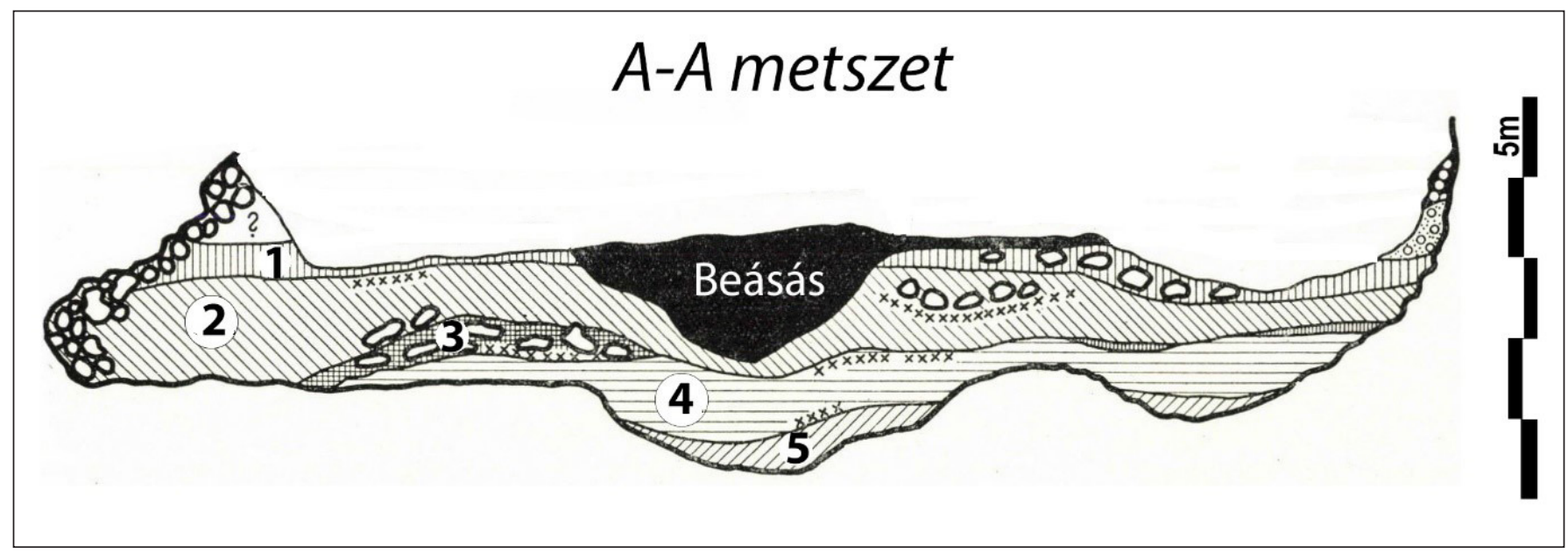

3. kép. Az 1951-es szelvény rétegtani metszete (VÉRTES 1955, Abb. 3b), a 2. kép A-A metszete

1) sárgásbarna löszös réteg kevés mészkőtörmelékkel;

2) mészkőtörmelékes sötétbarna kitöltés, amelynek a felső részében fordultak elő a felső kultúrréteg Aurignacien II régészeti leletei;

3) lilásszürke és vörös rétegfoszlányok, amelyben már az alsó kultúrréteg Aurignacien I leletei voltak;

4) világosbarna réteg apró mészkőtörmelékkel, amelynek teljes vastagságában az alsó kultúrréteg Aurignacien I leletei feküdtek;

5) helyben mállott mészkő.

Vértes végeztetett ugyan természettudományos vizsgálatokat, amelyek szerint a rétegek eltérö éghajlatú időszakokban keletkeztek (VÉRTES 1959), viszont az akkori ásatási technikáknak köszönhetően a mintavételi sűrüség a mai elvárásokhoz mérten ritka volt.

A régészeti leletanyag újabb feldolgozásai az Aurignacien kultúrába történő besorolását vagy megerősítették (PAтоu-Mathis et al. 2016), vagy elvetették (MARKó 2015; 2017). Annak a lehetősége, hogy többféle régészeti interpretáció is születhet, egyáltalán nem meglepő. Ezt a rétegeket ért utólagos bolygatások, a régi feltárási módszerek pontatlansága, és a dokumentáció hiánya teszi lehetővé. Markó András (2015; 2017) vetette fel, hogy az alsó kultúrréteg nem az Aurignacien kultúrához, hanem a Jankovich-, a Bivak- és a Vindija-barlang késői középső paleolit leletanyagaihoz hasonlít leginkább, míg a felső réteg (Aurignacien II) leletanyaga az 1947-et megelőző feltárások anyagával együtt a Bodrogkeresztúr-Henyén feltárt Gravettien kultúrához, a Szeleta-barlang felső, Gravettien rétegéhez és a kelet-szlovákiai Bárca II " „Aurignacien típusú” leleteihez áll közel.

Mivel az Istállós-kői-barlangot a nemzetközi kutatás az Aurignacien lelőhelyeként tartja számon, a lelőhely kiemelten fontos az őskőkor nemzetközi kutatásában (CHU 2018), és kulcsszerepet játszik a modern ember európai elterjedését magyarázó, „Duna-folyosó” modellben (CONARD \& Bolus 2003). Kelet-Közép-Európában ez az egyetlen olyan barlangi lelőhely, ahol egymás fölött két rétegben található meg az Aurignacien kultúra, s ráadásul az alsó réteg a modern ember egyik legkorábbi régészeti emlékét tartalmazza. A legutóbbi korhatározási eredmények szerint az alsó kultúrréteg kora megközelítőleg 40 ezer évre és a felső kultúrrétegé 34 ezer évre tehető, kalibrált naptári években értve (ADAMS 2002; Ringer 2002; Davies \& Hedges 2008-2009). Éppen ezért jelentős problémákat okoznak azok a bizonytalanságok is, amelyek az új korhatározások és a régészeti leletanyag összetartozása körül vetődnek fel. 
Lengyel György et al. • Ásatások az Istállós-köi-barlangban és az új kutatási eredmények

\section{A 2020-AS ÁSATÁS}

A kulturális és relatív időrendi bizonytalanságok kifejezetten arra sarkallnak, hogy a meglévő rétegsorból nagy felbontásban lehessen mintákat gyüjteni, és a mai elvárásoknak megfelelő természettudományos vizsgálatsorozattal az emberi megtelepedések idejét és környezetét pontosan rekonstruálni. A barlang leletegyüttese túl fontos ahhoz, hogy kétségekkel szerepeljen a nemzetközi kutatásban. Megoldást a barlang modern ásatási módszerekkel történő feltárása, a régészeti, paleontológiai, és paleobotanikai leletek, valamint az őket befoglaló üledékek multidiszciplináris feldolgozása hozhat. Ez hívta életre azt a projektet, amely 2020. augusztus-szeptemberében ásatást folytatott a barlangban. A terepi munkálatok egy hároméves kutatás részét képezik, amely a Miskolci Egyetem, az ELTE és a Lengyel Tudományos Akadémia együttmüködésében valósult meg a lengyel Nemzeti Tudományos Központ (NCN) támogatásával.

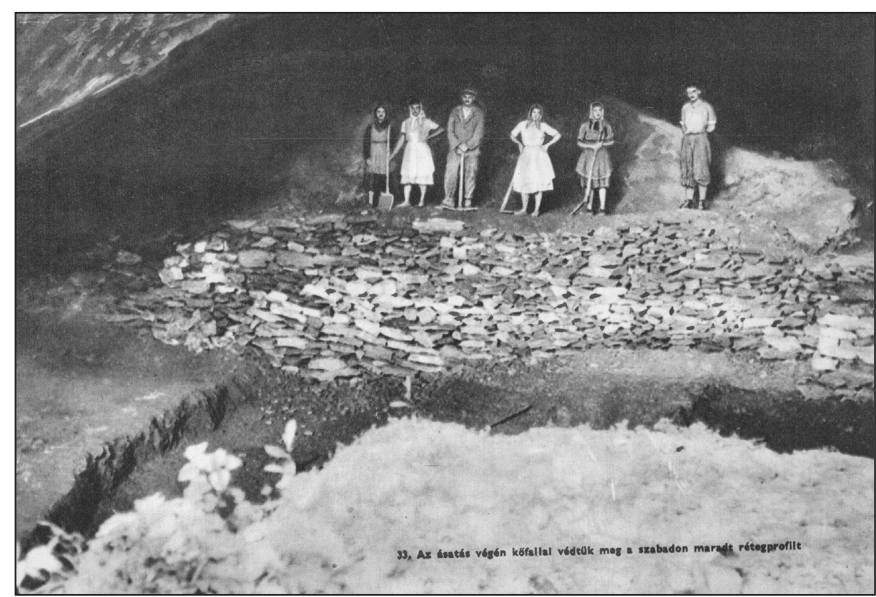

4. kép. Vértes László 1951-ben rakott köfala, amellyel a rétegtani szelvényt védte (VÉRTES 1957, 33. kép)

Vértes László az akkori az ásatási technikával 1950-1951-ben eltávolította szinte az összes üledéket a barlang első feléből. Az ásatási szelvények rekonstruálása alapján (VöRös 2003/2004) az 1947es tüzhely kiemelése és az 1951-es profil között található még mintegy $3 \mathrm{~m}$ széles sávja a barlangnak, ahol még a legteljesebb üledéksor található, a legfelső jelenkori réteg nélkül. Ez a barlang $460 \mathrm{~m}^{2}$ felületének töredékét teszi ki. A többi részen az üledéksor vagy teljesen hiányzik, vagy csak az alsóbb rétegek őrződtek meg. Mivel az Istállós-kői-barlang a Bükk fokozottan védett barlangjai közé tartozik, a lehető legkevesebb anyag eltávolításával kellett az új mintavételezést megoldani a meglévő rétegsorból.

Vértes László egy szárazon rakott kőfallal védte meg az 1951-ben kialakított keresztszelvényt az omlástól (4. kép). Innen indult a 2020-as ásatás. Először egy 3 m-es széles szakaszt nyitottunk ki a metszetfalból (5. kép), amelyet az ásatás végére 4,5 $\mathrm{m}$ hosszúra bővítettünk (6. kép). A geológiai rétegzettségen belül $2 \mathrm{~cm}$-es mesterséges szintekben bontottuk az üledéket. Minden egyes leletet (csont,

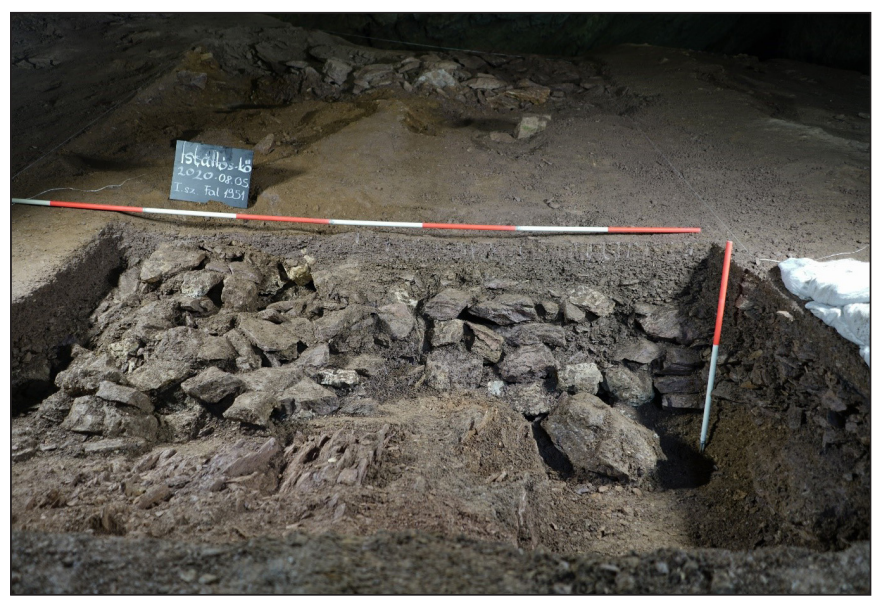

5. kép. Az 1951-es fal maradványa (a bejárat felöl nézve)

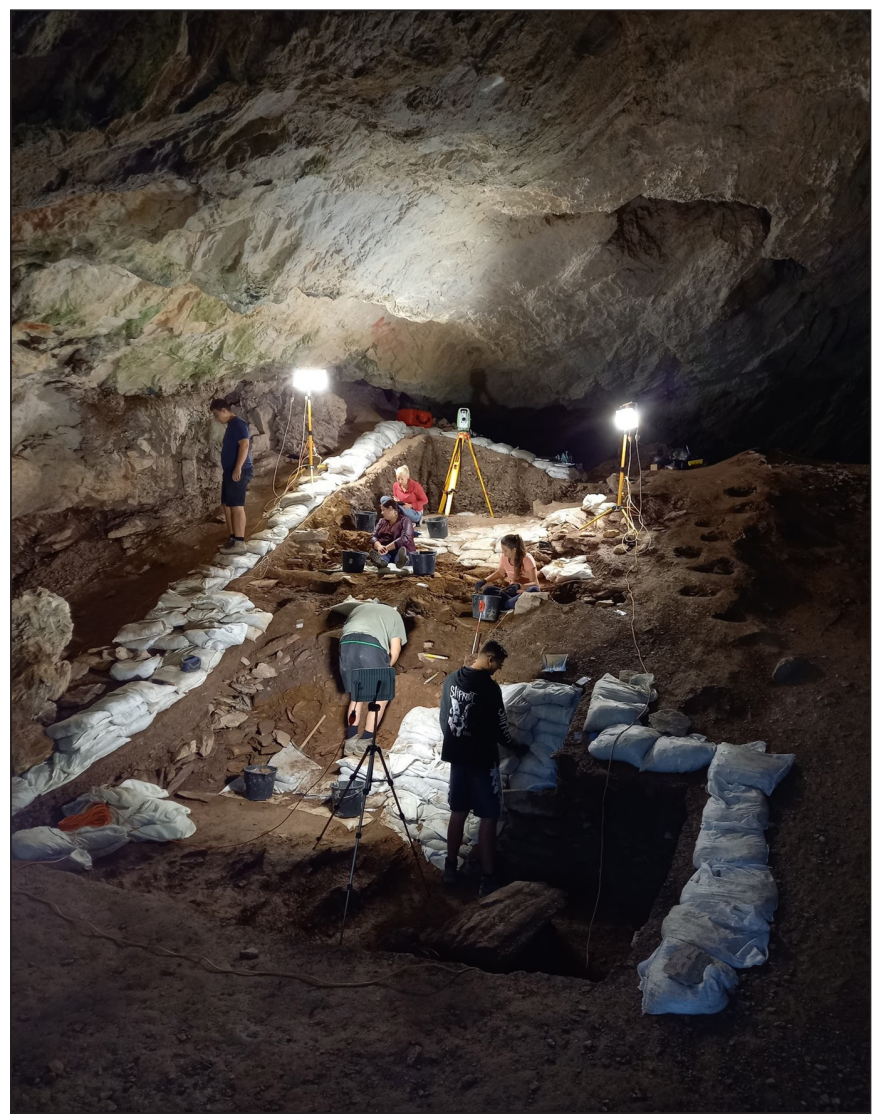

6. kép. Ásatás az Istállós-köi-barlangban 2000-ban 
Lengyel György et al. • Ásatások az Istállós-köi-barlangban és az új kutatási eredmények

agancs, kő, faszén) három koordinátával rögzítettünk digitális méröállomással (Leica Flexline TS03) és egyesével elcsomagoltuk a helyszínen. A kiásott üledéket a helyszínen átszitáltuk.

A barlang üledéksorából vett mintákon a következő vizsgálatokat végezzük el:

- üledékföldtani elemzés (mikromorfológia, szemcseméret, geokémia);

- pollenfeltárás;

- faszénmeghatározás;

- archeozoológiai feldolgozás;

- állati maradványok biokémiai vizsgálata $\left({ }^{18} \mathrm{O} /{ }^{16} \mathrm{O},{ }^{15} \mathrm{~N} /{ }^{14} \mathrm{~N},{ }^{13} \mathrm{C} /{ }^{12} \mathrm{C},{ }^{87} \mathrm{Sr} /{ }^{86} \mathrm{Sr}\right)$;

- radiokarbon kormeghatározás.

A feltárás pontos eredményei az elvégzendő természettudományos vizsgálatok után lesznek elérhetők, ezért itt a terepen megfigyelt tapasztalatokat összegezzük.

Vértes László 1951-ben rakott falának eredeti magasságából csak az alsó harmada maradt meg érintetlenül. Ez azt jelenti, hogy ma a barlang közepén húzódó rézsű felső $2 / 3-a$ az eredeti üledéksort csonkolja. Ebböl megbecsülhető, hogy 1951 óta több köbméter eredeti üledék erodálódott le és halmozódott fel a barlang első felében.

A rézsű megbontásakor a felső $5-10 \mathrm{~cm}$ jelenkori hulladékkal kevert és erösen bolygatott volt. Az ásatás során összességében $8 \mathrm{~m}^{2}$-nyi területen tártunk fel eredeti üledéket. Az 1947-es szelvény déli (a bejárat felé eső) fala élesen látszódik a profilban (7. kép). Ez az a terület, ahonnan a tüzhelyt kiemelték. Ennek során a barlangnak ez a középső része intenzíven bolygatottá vált.

Az említett $3 \mathrm{~m}$ széles területen a teljes rétegsor keresztmetszetét sikerült feltárnunk, de nem egyetlen profilban, hanem lépcsőkben eltolt metszetekben (8. kép). Fenékig egyedül egy $1 \times 1$ m-es négyzetből távolítottunk el érintetlen üledéket, összesen $75 \mathrm{~cm}$ vastagságban. Így összességében $3 \mathrm{~m}$ vastagságban kutattuk át az eredeti üledéket, és maximum 2,5 $\mathrm{m}^{3} \mathrm{-t}$ tártunk fel. Ezzel a módszerrel tetemes eredeti üledéket hagytunk érintetlenül a későbbi kutatások számára.

A kibontott metszetfalunkban azonosítottuk az 1951-es profil rétegeit, de a rétegsor lényegesen összetettebb, mint ahogyan azt Vértes László leírta. Az 1951-es profilban világossá vált, hogy Vértes László kb. 0,5 métert elbontott a szálkőböl is. Valószínủleg azért nem vette észre, hogy a szálkőzetnél

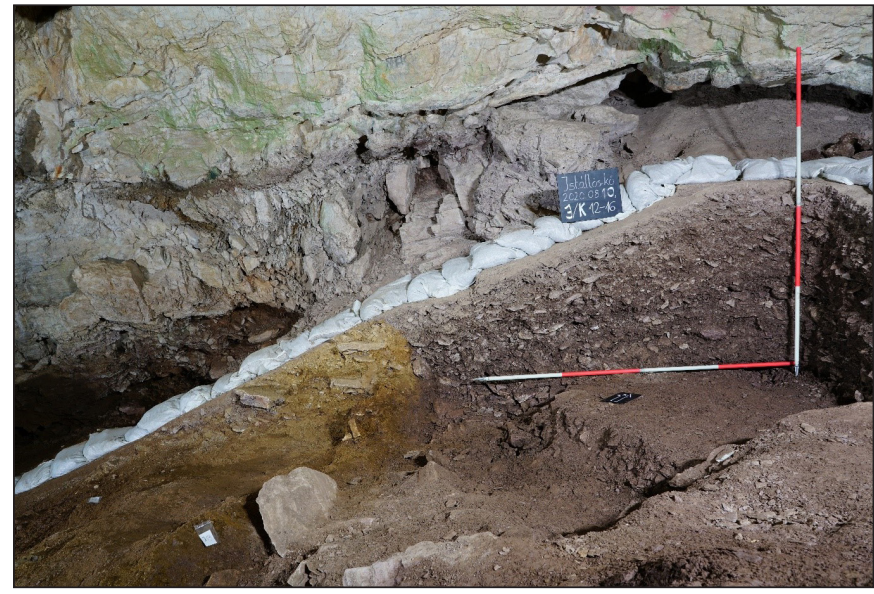

7. kép. Az 1947-ben kiemelt tüzhely visszatöltése (jobb oldali szürke üledék) és az érintetlen üledékek határa

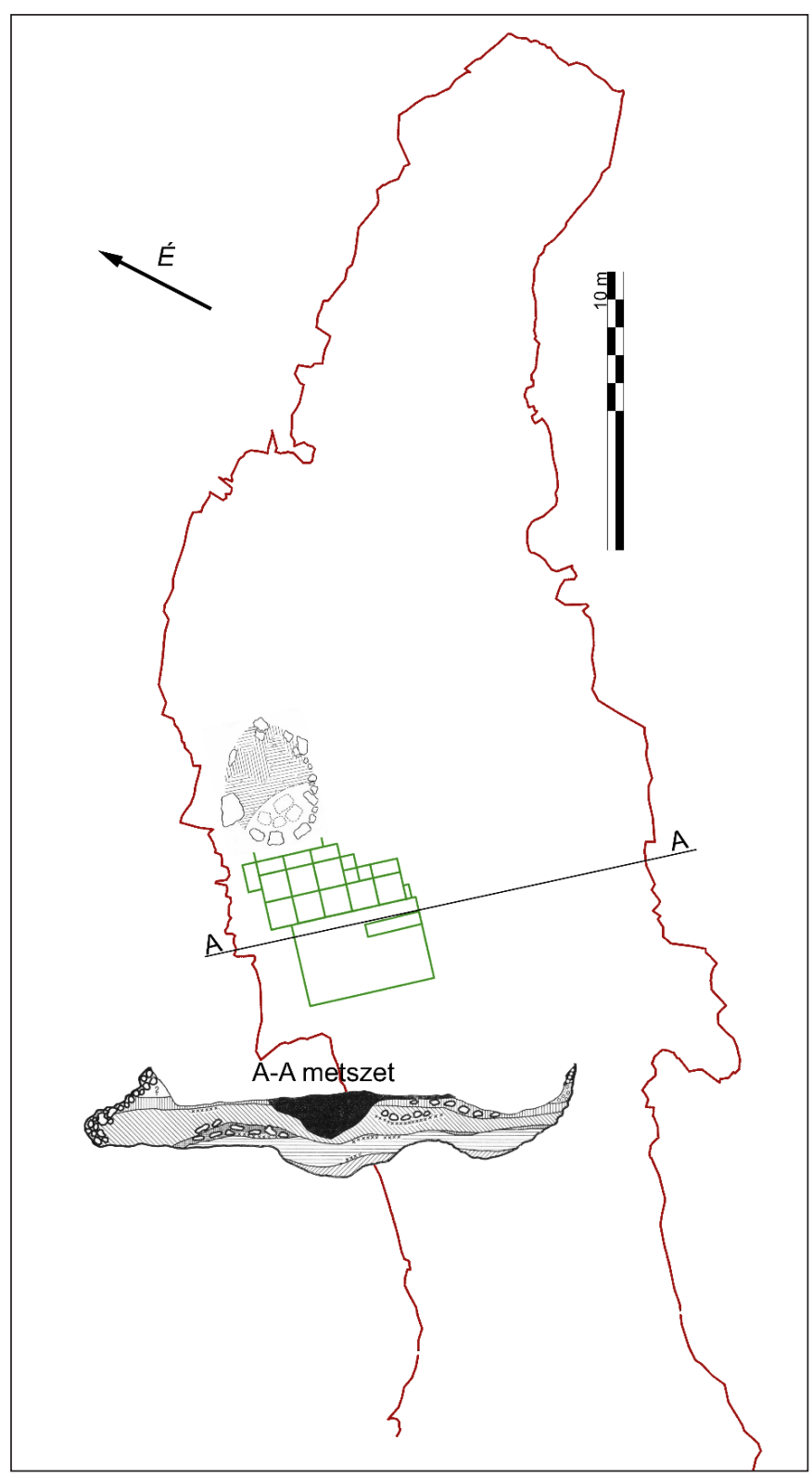

8. kép. A barlang alaprajza a 2020-as felmérés alapján, a szelvény elhelyezkedése az 1947-es tüzhely és az 1951-es keresztmetszet között 
Lengyel György et al. • Ásatások az Istállós-köi-barlangban és az új kutatási eredmények

jár, mert a barlangot magába foglaló mészkő lemezes szerkezetü, a lemezek kb. 80-85 fokos szögben dölnek a barlang jobb oldala felé, amelyek peremei könnyen mállanak és aprózódnak, ezért kézzel is könnyen elmozdíthatók. A feltárt rétegsort Vértes László négyes beosztása helyett mi 11 rétegre tudtuk felosztani. Az 1. táblázatban a terepi megfigyelések alapján leírható rétegsort mutatjuk be. Az üledékek további jellemzése a laboratóriumi vizsgálat után lesz lehetséges.

1. táblázat. Rétegtani korreláció az 1951-es és a 2020-as feltárás üledékei között

\begin{tabular}{|c|c|}
\hline 1951 & 2020 \\
\hline 1 & 1: sárga kis kőtörmelékes, $30 \mathrm{~cm}$ (9. kép) \\
\hline 1 & 2: barna apró kőtörmelékes, 10 cm (9. kép) \\
\hline 1 & 3: sárga kis kőtörmelékes, $20 \mathrm{~cm}$ (9. kép) \\
\hline 2 & 4: világosbarna, helyenként, foltokban lilás árnyalatú, nagy kőtörmelékes, $30 \mathrm{~cm}$ (9. kép) \\
\hline 2 & 5: sárga nagy kőtörmelékes, $20 \mathrm{~cm}$ (9-10. kép) \\
\hline 2 & 6: lila közepes kőtörmelékes, 30 cm (10. kép) \\
\hline 2 & 7: szürke, sötétszürke közepes kőtörmelékes, 15 cm (10. kép) \\
\hline 2 & 8: sárgásbarna nagy kőtörmelékes, $10 \mathrm{~cm}$ (10-11. kép) \\
\hline 3 & 9: lila, nagy kőtörmelékes, kevés üledék a kövek között, 50 cm (10-11. kép) \\
\hline 4 & 10: sárgás, világosbarna apró-kis kőtörmelékes, $80 \mathrm{~cm}$ (10-11. kép) \\
\hline 4 & 11: sötétbarna, apró kis kőtörmelékes, $20 \mathrm{~cm}$ (11. kép) \\
\hline
\end{tabular}

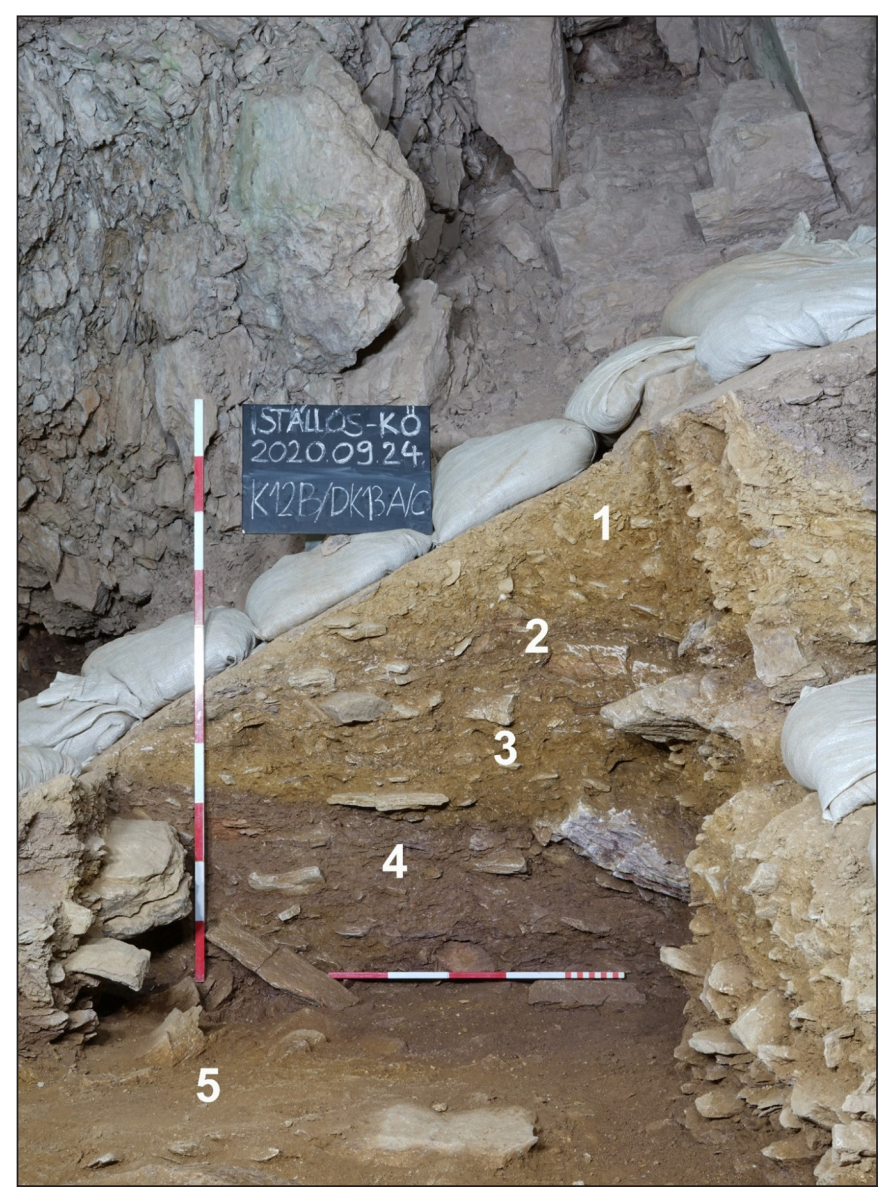

9. kép. A 2020-as rétegsor felsö része

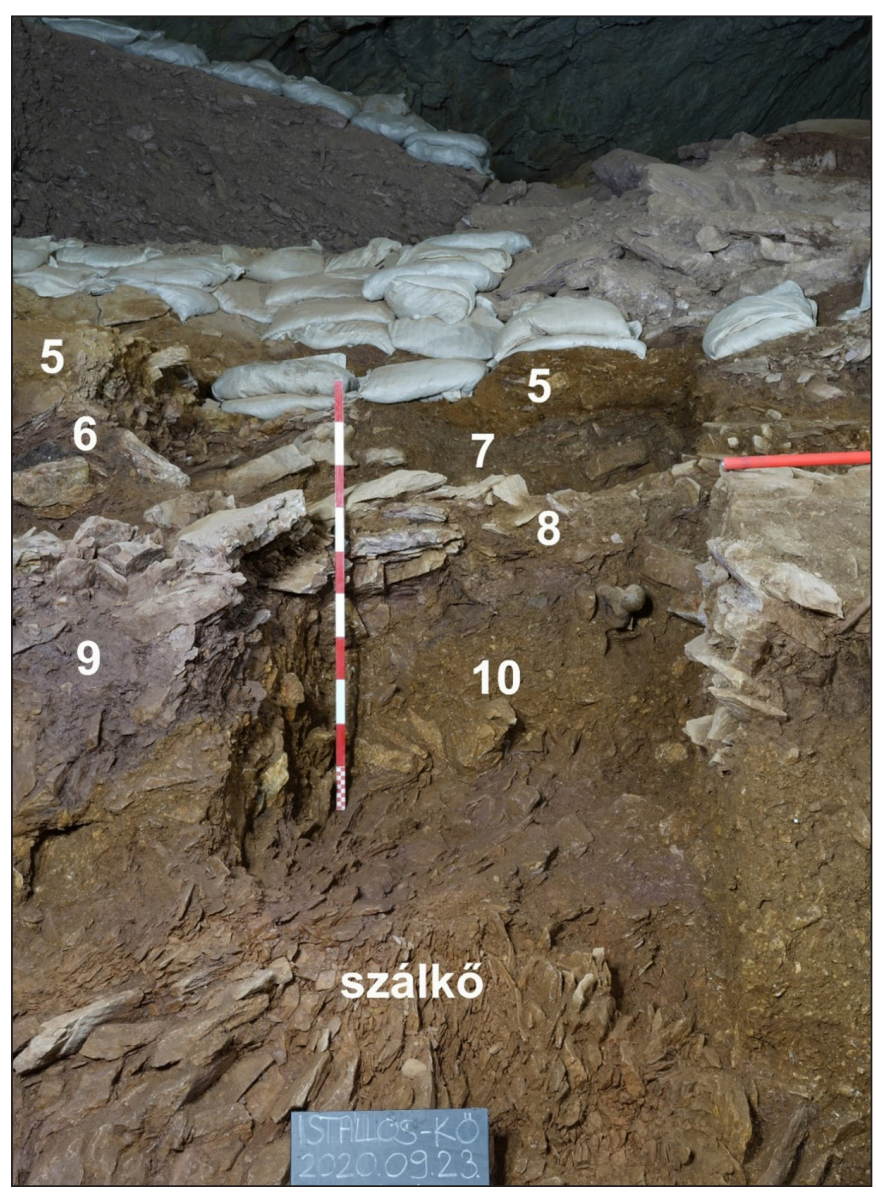

10. kép. A 2020-as rétegsor középső része 
Lengyel György et al. • Ásatások az Istállós-köi-barlangban és az új kutatási eredmények

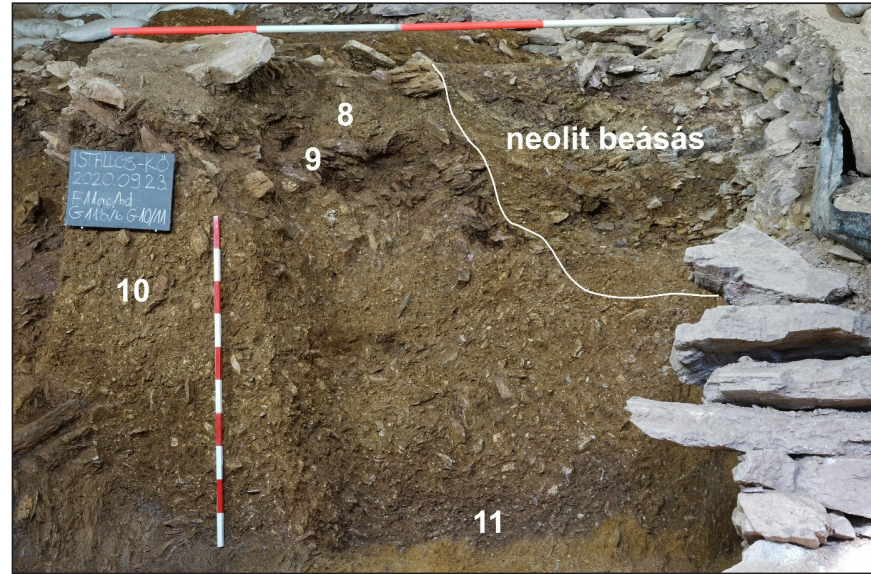

11. kép. A 2020-as rétegsor alsó része

A feltárt leletek 99\%-a állatcsont. Ezek nagy része barlangi medve, azonban a fajok rétegtani eloszlása csak az archeozoológiai feldolgozás után lesz világos. Egyelöre annyit tudunk, hogy van közöttük havasi nyúl, sarki róka, farkas és szarvasféle is. Több tüzelési nyomot is találtunk a rétegsorban, amelyek elsősorban az 5. és a 7. rétegünkhöz kapcsolódnak. Elszórtan találtunk faszeneket a többi rétegben is. Ásatásunk során egyetlen pattintott követ találtunk, ami egyáltalán nem meglepő, ha tekintetbe vesszük, milyen kevés kőeszköz került elő Vértes László feltárásain a kiásott üledék mennyiségéhez képest. A megtisztítást követően az állatcsontanyagban még rábukkanhatunk megmunkált csontokra, amelyeken az emberi alakítás nyomai az elökerüléskor még nem látszottak.

A részletesen tagolt rétegsorból vett üledékminta sok szempontú laboratóriumi elemzése, az állat- és növénymaradványokból levonható őskörnyezeti adatok, valamint a mintegy $50 \mathrm{db}$. betervezett radiokarbon dátum jelentősen elöre fogja vinni a lelőhely és az emberi megtelepedések történetének megértését.

\section{KÖSZÖNETNYILVÁNÍTÁS}

A kutatást támogatta a Narodowe Centrum Nauki (UMO-2019/33/B/HS3/02264), A Magyar Tudományos Akadémia Bolyai János Kutatási Ösztöndíja és Az Innovációs és Technológiai Minisztérium ÚNKP-21-5 kódszámú Új Nemzeti Kiválóság Programjának a Nemzeti Kutatási, Fejlesztési és Innovációs Alapja.

\section{FELHASZNÁLT IRODALOM}

Adams, B. (2002). New radiocarbon dates from Szeleta and Istállós-kő Caves, Hungary. Praehistoria 3, $53-55$.

Chu, W. (2018). The Danube Corridor Hypothesis and the Carpathian Basin: Geological, Environmental and Archaeological Approaches to Characterizing Aurignacian Dynamics. Journal of World Prehistory 31, 117-178. https://doi.org/10.1007/s10963-018-9115-1

Conard, N. J. \& Bolus, M. (2003). Radiocarbon dating the appearance of modern humans and timing of cultural innovations in Europe: new results and new challenges. Journal of Human Evolution 44, 331-371. https://doi.org/10.1016/S0047-2484(02)00202-6

Davies, W. \& Hedges, R. (2008-2009). Dating a Type Site: Fitting Szeleta Cave into its Regional Chronometric Context. Praehistoria 9-10, 35-45.

Hillebrand J. (1913). A pleistocaen ősember ujabb nyomai hazánkban. Barlangkutatás 1/1, 19-25.

Hillebrand J. (1914). Az 1913. évi barlangkutatásaim eredményei. Barlangkutatás 2/3, 115-124.

Hillebrand J. (1917). Az 1916. évi barlangkutatásom eredményéröl. Barlangkutatás 5/2, 98-108.

Hillebrand J. (1919). Az 1917. évben végzett ásatásaim eredményei. Barlangkutatás 7/1-4, 6-13. 
Lengyel György et al. • Ásatások az Istállós-köi-barlangban és az új kutatási eredmények

Kadić O. (1927). A magyar barlangkutatás állása az 1925. évben. Barlangvilág 1/1-4 (1926), 26-31.

Kadić O. \& Mottl M. (1944). Az északnyugati Bükk barlangjai. Barlangkutatás 17/1, 1-84.

Markó, A. (2015). Istállóskő revisited: Lithic artefacts and assemblages, sixty years after. Acta Archaeologica Academiae Scientiarum Hungaricae 66, 5-38. https://doi.org/10.1556/072.2015.66.1.1

Markó, A. (2017). Istállóskő revisited: The osseous artefacts from the lower layer. Acta Archaeologica Academiae Scientiarum Hungaricae 68, 193-218. https://doi.org/10.1556/072.2017.68.2.1

Patou-Mathis, M., Vercoutère, C., Lengyel, Gy., Szolyák, P. \& Mester, Zs. (2016). New interpretation of the Upper Palaeolithic human occupations at Istállóskő Cave (Bükk Mountains, Hungary). Eurasian Prehistory 13/1-2, 77-90.

Ringer, Á. (2002). The new image of Szeleta and Istállós-kő caves in the Bükk Mountains: a revision project between 1999-2002. Praehistoria 3, 47-52.

Saád A. (1929). A Bükk hegységben végzett újabb kutatások eredményei. Archaeologiai Értesítő 43, 238247.

Székely K. (2002). Fokozottan védett barlangok. In: Baráz Cs. (szerk.), A Bükki Nemzeti Park. Hegyek, erdők, emberek (pp. 177-193). Eger: Bükki Nemzeti Park Igazgatóság.

Vértes L. (1951). Újabb ásatások az Istállóskői barlangban. Magyar Tudományos Akadémia II. TársadalmiTörténeti Tudományok Osztályának Közleményei 1/1, 11-40.

Vértes, L. (1955). Neuere Ausgrabungen und paläolithische Funde in der Höhle von Istállóskő. Acta Archaeologica Academiae Scientiarum Hungaricae 5, 111-131.

Vértes L. (1957). Medveemberek krónikája. Budapest: Gondolat Kiadó.

Vértes, L. (1959). Untersuchungen an Höhlensedimenten. Methode und Ergebnisse. Régészeti Füzetek Ser. II, 7, Budapest: Magyar Nemzeti Múzeum - Történeti Múzeum.

Vörös, I. (2003/2004). Stratigraphy and biostratigraphy of Istállóskő Cave. Praehistoria 4-5, 33-76. 